\title{
Who wants to be a citizen scientist? Identifying the potential of citizen science and target segments in Switzerland
}

\author{
Füchslin, Tobias ; Schäfer, Mike S ; Metag, Julia
}

\begin{abstract}
Driven by the proliferation of digital media, citizen science - the involvement of non-scientists in scientific research - represents one of the most important recent developments in science communication as it brings science and the public closer together. So far, however, citizen science projects have mostly attracted people that are highly educated, mostly male and already have very positive attitudes towards science. Based on nationally representative survey data $(\mathrm{N}=1051)$, our study explores the potential of citizen science in Switzerland. Using regression analysis, we show that attitudes towards science are significant antecedents of respondents' interest in participating in citizen science - but that gender and education are not. In addition, latent class analysis identifies five segments, representing over one-third of the Swiss population, who are interested in citizen science and could potentially be engaged: 'Free-Timers', 'Senior Sciencephiles', 'Young Sciencephiles', 'Intrigued Adolescents' and 'Fully Employed Parents'. Additional description suggests that previously overlooked segments are best addressed online via YouTube or offline in zoos or botanical gardens. Overall, our analysis suggests that citizen science's potential is far higher than previous projects were able to realize.
\end{abstract}

DOI: https://doi.org/10.1177/0963662519852020

Posted at the Zurich Open Repository and Archive, University of Zurich

ZORA URL: https://doi.org/10.5167/uzh-172695

Journal Article

Accepted Version

Originally published at:

Füchslin, Tobias; Schäfer, Mike S; Metag, Julia (2019). Who wants to be a citizen scientist? Identifying the potential of citizen science and target segments in Switzerland. Public Understanding of Science, 28(6):652-668. DOI: https://doi.org/10.1177/0963662519852020 


\title{
Who wants to be a citizen scientist? Identifying the overall potential of citizen science and target segments in Switzerland
}

\section{Authors}

\author{
Tobias Füchslin, University of Zürich, Switzerland \\ Mike S. Schäfer, University of Zürich, Switzerland \\ Julia Metag, University of Fribourg, Switzerland
}

\section{ORCID iD}

Tobias Füchslin https://orcid.org/0000-0002-2395-9674

Mike S. Schäfer https://orcid.org/0000-0002-0847-7503

Julia Metag https://orcid.org/0000-0003-4328-6419

\section{Abstract}

Driven by the proliferation of digital media, citizen science - the involvement of non-scientists in scientific research - represents one of the most important recent developments in science communication as it brings science and the public closer together. So far, however, citizen science projects have mostly attracted people that are highly educated, mostly male and already display very positive attitudes towards science. Based on nationally representative survey data $(\mathrm{N}=1051)$, our study explores the potential of citizen science in Switzerland. Using regression analysis, we show that attitudes towards science are significant antecedents of respondents' interest in participating in citizen science but that gender and education are not. Latent class analysis identifies five segments, representing over one third of the Swiss population, who are interested in citizen science and could potentially be engaged: "Free-Timers", "Senior Sciencephiles", "Young Sciencephiles", "Intrigued Adolescents", and "Fully Employed Parents". Additional description suggests that previously overlooked segments are best addressed online via YouTube or offline in zoos or botanical gardens. Overall, our analysis suggests that citizen science's potential is far higher than previous projects were able to realise.

Keywords: citizen science, science attitudes and perceptions, science communication, survey, Switzerland

\section{Keywords}

citizen science, science attitudes and perceptions, science communication, survey, Switzerland

\section{Corresponding Author}

Tobias Füchslin, Department of Communication and Media Research (IKMZ), University of Zürich, Andreasstr. 15, CH-8050 Zürich, / +41 (0)44 635 20 46, t.fuechslin@ikmz.uzh.ch

\section{Acknowledgements}

We would like to thank the reviewers for their valuable feedback on this article.

\section{Author Biographies}

Tobias Füchslin MA is a research and teaching associate at the division for science communication at the Department of Communication and Media Research (IKMZ), University of Zürich. His research focuses on attitudes towards science and research, scientific literacy, and citizen science. 
Dr. Mike S. Schäfer is professor for science communication at the University of Zurich's Department of Communication and Media Research (IKMZ) and Director of the university's Center for Higher Education and Science Studies (CHESS). His research focuses on science communication and climate change communication, particularly online.

Dr. Julia Metag is professor for communication science at the University of Fribourg's Department of Communication and Media Research (DCM), Switzerland. Her research focuses on political communication, science communication, and media effects.

\section{Funding}

This work was supported by Gebert Rüf Stiftung [grant number GRS-025/15]; and Stiftung Mercator Schweiz [grant number 2014-0607]. 


\section{Introduction, Relevance and Research Question}

Science and society have moved closer together in recent decades. This mutual approximation has been described as scientific knowledge production moving from "mode 1" to "mode 2" (Gibbons et al., 1994) or towards "contextualized science" (Nowotny, Scott, \& Gibbons, 2001) or as a general "societalization" of science (Weingart, 2001). The emergence and rise of digital media and particularly of online and social media have catalysed this approximation in recent years. They have established new interfaces between science and society (Dickel \& Franzen, 2016) that allow non-scientists to interact with science in novel ways - or at least to considerably scale up opportunities for interaction even though they may have existed before: non-scientists can now be witnesses to "science in the making" in livestreams from the NASA control room or Twitter feeds from scientific conferences. They can be discussion partners of scientists in online boards and fora (e.g., Zavestoski, Shulman, \& Schlosberg, 2016). They can be watchdogs in post-publication peer review online, or on plagiarism Wikis (e.g., Fähnrich, Janssen Danyi, \& Nothhaft, 2015). They can finance science via crowdfunding (e.g., Schäfer, Metag, Feustle, \& Herzog, 2016). And they can participate in research by becoming citizen scientists.

Citizen science (CS) - the involvement of non-scientists in scientific research - has been described as "perhaps the most dramatic development in science communication in the last generation" (Lewenstein, 2016). Even though early forms of citizen participation date back to the $17^{\text {th }}$ century (MillerRushing, Primack, \& Bonney, 2012), online media have moved citizen science to new heights recently. Including citizens in scientific research projects has become common practice in many fields, such as astronomy, biology, and ecology (Kullenberg \& Kasperowski, 2016), with more than 1'400 projects listed on CS platform SciStarter (2018) alone. For scientists as well as many societal stakeholders, CS holds strong promises: CS enables researchers to tackle amounts of data and analysis that would otherwise be unattainable by utilising crowd resources which help researchers (Nature, 2015). It promises positive effects on participants' scientific literacy and attitudes towards science (Bonney et al., 2009). More generally, CS is seen as a way to 'democratise' science by incorporating many-and many diverse - participants in the research process, thus strengthening of the bond between science and society (Irwin, 1995).

The promises have already turned out to be true. Many CS projects have been realized and resulted in thousands of academic publications (Kullenberg \& Kasperowski, 2016). Project evaluations indicate that CS projects can indeed increase participants' scientific knowledge as well as their attitudes towards science and research (Bonney, Phillips, Ballard, \& Enck, 2016; Pandya \& Dibner, 2018). When it comes to including many, and many diverse, citizen scientists in the respective projects, however, CS seems to have reached its boundaries. Studies unveil that volunteers for CS projects are mostly male, highly educated and display favourable attitudes towards science before their participation already (Curtis, 2018; Haklay, 2018). Fittingly, Bonney et al. (2016, p. 12) conclude that "if the field of citizen science is to truly contribute to democratizing science, then it must strive to reach a wider range of audiences and participants."

Two factors might stop project organisers from reaching a more diverse set of participants and, thus, realising CS's full potential: it could be that they are either not aware of certain groups' interest in CS, or that project organisers are not adequately reaching or addressing those interested (West \& Pateman, 2016). To this date, it remains an open question how large the overall potential of CS is, which factors shape people's participation, and how a wider circle of participants could be mobilized (Lewenstein, 2016). 
Questions regarding the factors increasing interest in participation as well as how to address interested people cannot be answered by analysing participants of CS projects themselves, as such samples are subject to a strong selection bias. Nationally representative samples, however, provide the right basis to answer these questions. Therefore, our study analyses nationally representative survey data from Switzerland - a country that has seen an increase in domestic citizen science projects and is building an infrastructure to become one of the world's main players in citizen science (Science et Cité, 2015). Based on this data, we aim to identify the overall potential of CS in the country.

The analysis is guided by three research questions: we first look at the question of identifying potential participants by comparing people with very low to very high degrees of interest in CS and analysing the general characteristics that shape their potential participation, asking

\section{(RQ1) what characteristics predict people's intention to participate in CS projects in Switzerland?}

Afterwards, we focus on ways to improve the likelihood to reach potential participants for CS in Switzerland by addressing the two potentially limiting factors: not being aware of or inadequately addressing target groups. We identify specific segments within the subset of the population that displays a general willingness to participate in citizen science (RQ2) and analyse ways to address these segments by describing them in terms of their topical interests and the communication channels that are most likely to reach them (RQ3).

(RQ2) Among Swiss citizens interested to participate in CS, which segments can be differentiated?

(RQ3) What are the best ways to address the segments with regards to their topical interests and commonly used communication channels?

\section{Literature Review}

Participation in CS projects can be broken down into stages. For volunteerism in general, Penner (2002) proposed to differentiate between the decision to volunteer, the first volunteering actions (initial volunteerism), and long term engagement (sustained volunteerism). Using this heuristic, a considerable number of studies has analysed people's motivations during their participation in CS projects (Curtis, 2018). Our study, however, focuses on the previous stage where people are still deciding whether to participate in CS.

As we show in the following, previous research has barely addressed this stage, and therefore, scholars are unclear about the factors that shape participation in CS (Lewenstein, 2016, p. 1). When aiming to identify such factors, however, it is still useful to survey previous scholarship about online and offline CS projects.

On the one hand, presentations and evaluations of online CS projects often contain participant descriptions based on survey data. Those descriptions mostly focus on sociodemographic factors and people's interests. Curtis (2018) delivers a comprehensive overview and summary of characteristics of people that participate in online CS. She concludes that "the available data suggests that the typical participant is likely to be a well-educated male with an existing interest in science or computing" (Curtis, 2018, p. 168). Based on her own data, she also noticed that respondents "demonstrate a wider interest in science and report taking part in science-related activities such as reading popular science books, visiting science centres, and looking at science-related websites" (Curtis, 2018, p. 60).

On the other hand, it is useful to look at offline CS projects as well. Even though there are no summaries similar to Curtis (2018) available for offline CS projects, the characteristics of participants from recent studies also seems to indicate that they are mostly men (Alender, 2016; Land-Zandstra, Devilee, Snik, 
Buurmeijer, \& van den Broek, 2016) and highly educated (Alender, 2016; Land-Zandstra et al., 2016; Lynch, Dauer, Babchuk, Heng-Moss, \& Golick, 2018). What many studies show additionally is that participants have a high interest in science or the more specific project topic, as well as very positive attitudes towards science (Dean, Church, Loder, Fielding, \& Wilson, 2018; Lynch et al., 2018). When it comes to people's age, results are more varied, ranging from samples mainly consisting of retired people (Alender, 2016) to more balanced examples (Dean et al., 2018).

A recent analysis of 68 online as well as offline CS projects representing a total sample of 65'336 participants confirms the unequal participation patterns observed in other studies, concluding that "there were striking patterns in the reported participant demographics which generally described a slightly male-biased, overwhelmingly white, and well-educated population with somewhat of a tendency to have previously participated in other projects" (Pandya \& Dibner, 2018, p. 143).

Sample descriptions make clear that citizen science projects seem strongly affected by "participation inequality" (Haklay, 2018). It is noteworthy, however, that studies' descriptions of CS participants online and offline are biased by self-selection in two ways: they only describe people who participated in a CS project and who additionally opted to participate in a survey. Any analysis of CS participants, however, is unable to assess whether CS has reached its boundaries or whether it could attract other potential participants with certain characteristics. Only a general population sample can answer such questions. So far, only one study used such a general sample with a "focus on potential volunteers for marine citizen science rather than only volunteers who have already been recruited in citizen science projects" (Martin, 2017, p. 143) - but this study was limited to a specific setting and topic. For coastal Australia, Martin (2017) looked at 1'145 marine users (i.e., fishers, divers, beach users, etc.) and ascertained their willingness to participate in CS. While this study suggests that people with more positive attitudes towards science are more willing to participate and invest hours in CS projects, the role of sociodemographic factors remains unexplored. Furthermore, the study was not representative of the whole country and seemed to survey a very forthcoming part of the population where only six respondents were not interested in helping scientific research.

\section{Methodology}

\section{Data}

We ran a secondary analysis of a nationally representative data set - the "Science Barometer Switzerland" ("Wissenschaftsbarometer Schweiz") - from 2016 that ascertained the Swiss' willingness to partake in scientific research projects (for an overview see Schäfer, Füchslin, Metag, Kristiansen, \& Rauchfleisch, 2018). The survey generally covers common science communication variables ranging from attitudes towards, beliefs in, and knowledge about science to a wide spectrum of media and non-media sources with which respondents could come into contact with science and research. Based on public telephone listings (90\% landlines, $10 \%$ mobile), households were randomly selected, household members were chosen according to sex and age quotas and were interviewed using computer-assisted telephone interviews. A total of 1051 respondents participated (651, 200, 200 from the German-, French-, and Italian-speaking parts of the country, respectively). The final sample was weighted regarding cantons, size of living area, gender, age, education, occupation, and household size. 
Regarding RQ1, we ran a linear regression ${ }^{1}$ to correlate people's interest in participating in CS. While this secondary analysis benefited from nationally representative data, we were limited by only having one item available to access interest in CS. The item for the dependent variable was "I would like to participate in scientific research projects (once)"2, with interviewers instructed to explain if necessary that participating on research did not mean being the object of analysis but active participation in data acquisition and/or data analysis. Answers could range from 1="do not agree at all" to $5=$ "agree strongly". Responses to this item were then modelled using two sets of commonly used explanatory variables:

We first used traditional sociodemographic variables (Table 1). They cover people's age; their gender (\% female); education (\% tertiary education); occupation status (\% fulltime employed); household situation (\% living in households with children); and their proximity to science, which is a sum-index (04) representing whether people are scientists themselves (4 points), or whether they personally know a scientist, work in a science-related environment, or have family members that (used to) study at a university (one point per affirmation). Additionally, we included a global measure of people's political orientation (1="left" ... 7="right") and religiosity (1="not at all religious" ... 5=" very religious") (Besley, 2018; Runge, Brossard, \& Xenos, 2018).

A second set of indicators covered attitudes toward science (Schäfer et al., 2018), which we measured regarding cognitive, affective, and conative aspects (Table 1):

- To assess the cognitive aspect, we measured respondents' knowledge about science. Knowledge about science is often assessed via quiz statements focusing on STEM subjects in surveys, e.g., "Electrons are smaller than atoms" (Kawamoto, Nakayama, \& Saijo, 2013; Miller, 1983). As this quiz format has been criticized (e.g., Pardo \& Calvo, 2002, 2004), however, we use it in adapted form. First, we included questions about arts and humanities, about textbook and applied scientific knowledge, and also about the process of science (Schäfer et al., 2018). Second, we moved from the established dichotomous "correct-false" answer format, which gives respondents a 50\% random chance to answer correctly to a format allowing respondents to indicate the level of certainty in their answers (Taddicken, Reif, \& Hoppe, 2018). Answers for the 11 items were combined in an index: correct answers gave respondents one point for the "likely" and two points for the "definitely" version. Incorrect or "do not know" answers were assigned zero points. The index value is the arithmetical mean of points per question, ranging from 0 to 2 . In addition to knowledge, we asked for respondents' interest in science, employing a question that was widely used in several surveys (Besley, 2013).

- The affective aspect of attitudes was measured by asking respondents for their general trust in science (Lee, Scheufele, \& Lewenstein, 2005), as well as for their assessment of whether science plays an important role in their lives (Schäfer et al., 2018).

- We assessed the conative aspect - as the behavioural component of attitudes is often operationalized in studies of science communication (Bauer, 2016; Eurobarometer, 2005) - with a question asking whether respondents actively search for information about science (Wissenschaft im Dialog, 2015).

Table 1: Items used in our study

\begin{tabular}{|l|l|c|c|}
\hline Dimension & Items & $\mathbf{N}$ & $\mathbf{M}$ \\
\hline
\end{tabular}

\footnotetext{
${ }^{1}$ We checked model assumptions - no assumptions were violated - and ran the model in R using the "sjPlot" package (Lüdecke (2018).

2 The original wording in German is: "Ich würde gern einmal in wissenschafltichen Projekten mitforschen". The "once" in the English translation should be understood as "once or more".
} 


\begin{tabular}{|c|c|c|c|c|}
\hline $\begin{array}{l}\text { Interest in Citizen } \\
\text { Science }\end{array}$ & $\begin{array}{l}\text { I would like to participate in scientific research projects (once) } \\
\text { (1="do not agree at all" ... 5="agree strongly") }\end{array}$ & 1043 & 2.86 & 1.39 \\
\hline \multirow[t]{2}{*}{$\begin{array}{l}\text { Attitudes towards } \\
\text { Science \& Research } \\
\text { Cognitive }\end{array}$} & $\begin{array}{l}\text { Scientific Literacy } \\
\text { (index: } 0-2 \text {; no/incorrect answer=0 pts., correct "likely" -answer=1 pt., correct "defi- } \\
\text { nitely"-answer =2pts.) }\end{array}$ & 1051 & 1.23 & 0.36 \\
\hline & $\begin{array}{l}\text { How interested are you in science and research? } \\
(1=" \text { not at all interested" } \ldots 5=\text { ="very interested") }\end{array}$ & 1050 & 3.45 & 1.11 \\
\hline \multirow[t]{2}{*}{ Affective } & $\begin{array}{l}\text { Science and research play an important role in my life } \\
\text { (1="do not agree at all" ... 5="agree strongly") }\end{array}$ & 1044 & 3.14 & 1.19 \\
\hline & $\begin{array}{l}\text { How high is your trust in science in general? } \\
(1=" \text { very low" ... 5="very high") }\end{array}$ & 1042 & 3.58 & 0.74 \\
\hline Conative & $\begin{array}{l}\text { I specifically search for information about science and research } \\
\text { (1="do not agree at all" ... 5="agree strongly") }\end{array}$ & 1048 & 3.13 & 1.35 \\
\hline \multirow[t]{8}{*}{ Sociodemographics } & Gender (percent female) & 1051 & 50.8 & - \\
\hline & Age (years) & 1051 & 46.3 & 17.90 \\
\hline & Education (percent tertiary education) & 1046 & 43.3 & - \\
\hline & Proximity to science (index: $0-4$ ) & 1049 & 1.59 & 1.26 \\
\hline & Household situation (percent living in households with children) & 1048 & 69.7 & - \\
\hline & Occupation status (percent who work full-time) & 1043 & 36.4 & - \\
\hline & Religiosity (1="not at all religious" ... 5=" very religious") & 1047 & 2.72 & 1.25 \\
\hline & Political Orientation (1="left" ... 7="right") & 998 & 3.64 & 1.28 \\
\hline \multirow[t]{7}{*}{$\begin{array}{l}\text { Interest in Scientific } \\
\text { Topics }\end{array}$} & $\begin{array}{l}\text { How interested are you in ... (1="not at all interested" ... 5="very interested") } \\
\text {... Medicine }\end{array}$ & 1050 & 3.82 & 1.05 \\
\hline & ... Environment \& Energy & 1051 & 3.92 & 0.93 \\
\hline & ... Biology & 1048 & 3.27 & 1.22 \\
\hline & ... Space Exploration & 1048 & 2.57 & 1.63 \\
\hline & ... Political Science & 1049 & 2.92 & 1.34 \\
\hline & ... Psychology & 1051 & 3.27 & 1.41 \\
\hline & ... History & 1050 & 2.98 & 1.49 \\
\hline \multirow[t]{7}{*}{$\begin{array}{l}\text { Legacy Media Con- } \\
\text { tact with Science } \\
\text { and Research }\end{array}$} & $\begin{array}{l}\text { How often do you come in contact with science and research via ... (1="never" } \ldots \\
5=\text { "very often") } \\
\ldots \text { Swiss Public Television (SRF) }\end{array}$ & 1045 & 2.86 & 1.20 \\
\hline & ... Other Television & 1034 & 2.65 & 1.23 \\
\hline & ... Swiss Public Radio (SRF Radio) & 1040 & 2.36 & 1.29 \\
\hline & ... Other radio & 1036 & 1.64 & 1.00 \\
\hline & ... Daily/Weekly newspapers and magazines & 1042 & 3.28 & 1.22 \\
\hline & ... Science magazines & 1032 & 1.95 & 1.28 \\
\hline & ... Internet & 1045 & 3.12 & 1.38 \\
\hline \multirow[t]{7}{*}{$\begin{array}{l}\text { Online Contact with } \\
\text { Science and Re- } \\
\text { search }\end{array}$} & ... Online outlets of newspapers and magazines & 1042 & 2.23 & 1.33 \\
\hline & ... Online archives of television and radio channels & 1039 & 1.90 & 1.14 \\
\hline & ... Institutional websites (scientific, government, organizations) & 1041 & 2.31 & 1.28 \\
\hline & ... Facebook & 1044 & 1.55 & 1.06 \\
\hline & ... Blogs or message boards & 1042 & 1.54 & 0.90 \\
\hline & ... Wikipedia & 1040 & 2.72 & 1.40 \\
\hline & ... YouTube or similar video platforms & 1043 & 2.22 & 1.29 \\
\hline \multirow[t]{6}{*}{$\begin{array}{l}\text { Other Contact with } \\
\text { Science and Re- } \\
\text { search }\end{array}$} & $\begin{array}{l}\text { How often do you do one of the following ... (1="never" ... 5="very often") } \\
\text {... Visit museums and exhibitions covering science and research }\end{array}$ & 1049 & 2.47 & 1.08 \\
\hline & ... Visit zoos, aquariums or botanical gardens & 1050 & 2.71 & 1.13 \\
\hline & ... Attend events, talks, discussions concerning science and research & 1050 & 2.09 & 1.09 \\
\hline & ... Read nonfiction books on science and research & 1051 & 2.51 & 1.28 \\
\hline & ... Watch movies related to science and research in the cinema & 1049 & 2.32 & 1.18 \\
\hline & ... Talk about science and research with friends and acquaintances & 1051 & 3.11 & 1.12 \\
\hline
\end{tabular}

For RQ2, we ran latent class analyses - a model-based clustering technique (Chapman \& Feit, 2015) with the subset of the overall population that "agreed" or "strongly agreed" to the question whether they would like to participate in scientific research projects $\left(\mathrm{N}_{\text {subset }}=381\right)$. Employing all explanatory variables from our regression models, we determined optimal solutions from one up to eight clusters using LatentGold 5.1 software (Vermunt \& Magidson, 2016). We entered 5000 random sets of starting values into the algorithm to ensure valid and robust solutions (see Appendix for full specifications). BIC values, which assess solutions by balancing between a minimum of unexplained variation in the dependent variable and a low number of explanatory variables, favoured the five-cluster solution (see Appendix). Since this solution also offered a clear interpretation of the five segments, we chose this 
solution. For presentation of results, we use the modal attribution of cases; that is, we assigned each respondent to her or his most probable segment. For more than $99.7 \%$ of respondents, the likelihood of belonging to one segment exceeded $50 \%$. The overall hit rate-defined as the sample mean of all respondents' posterior probabilities (Gollwitzer, 2012)-reached $94 \%$, meaning that survey respondents were, on average, $94 \%$ likely to belonging to one specific segment.

For RQ3, we further detailed the description of the newly identified segments by adding variables about people's topical interests and the channels of information through which they come into contact with science and research. The latter included 1) legacy media, 2) online media and 3) other forms of contact with science and research like conversations with friends or visits to museums and zoos (Table 1). 


\section{Results}

RQ1: Who is willing to participate in CS?

Table 2: Regression model for people's willingness to participate in scientific research projects

\begin{tabular}{|c|c|c|c|}
\hline \multirow[b]{2}{*}{ Explanatory Variables } & \multicolumn{3}{|c|}{$\begin{array}{c}\text { DV: „I would like to participate in scientific re- } \\
\text { search projects (once)“ }\end{array}$} \\
\hline & Std. Betas & $\mathrm{Cl}$ & $p$ \\
\hline (Intercept) & -0.02 & $-0.07-0.04$ & 0.231 \\
\hline Age & -0.12 & $-0.18--0.07$ & $<0.001$ \\
\hline Female $(1=$ yes, $0=$ no $)$ & -0.01 & $-0.07-0.05$ & 0.689 \\
\hline Tertiary Education ( $1=$ yes, $0=$ no $)$ & -0.00 & $-0.06-0.06$ & 0.921 \\
\hline Household with Children ( $1=$ yes, $0=$ no $)$ & 0.09 & $0.04-0.15$ & 0.001 \\
\hline Full-time Work ( 1 = yes, 0 = no) & -0.00 & $-0.06-0.05$ & 0.886 \\
\hline Political Orientation (left:1-7:right) & 0.02 & $-0.04-0.07$ & 0.54 \\
\hline Religiosity (1-5) & -0.02 & $-0.07-0.03$ & 0.487 \\
\hline Proximity to Science (0-4) & 0.07 & $0.01-0.13$ & 0.02 \\
\hline Scientific Literacy (0-2) & 0.02 & $-0.04-0.07$ & 0.567 \\
\hline Trust in Science (1-5) & 0.03 & $-0.03-0.09$ & 0.313 \\
\hline Interest in Science (1-5) & 0.14 & $0.08-0.21$ & $<0.001$ \\
\hline Personal Life-Relevance of Science (1-5) & 0.36 & $0.30-0.43$ & $<0.001$ \\
\hline Science Information Seeking (1-5) & 0.12 & $0.05-0.18$ & $<0.001$ \\
\hline Observations & 952 & & \\
\hline $\mathrm{R}^{2} /$ adjusted $\mathrm{R}^{2}$ & $0.360 /$ & & \\
\hline
\end{tabular}

Among our 1051 respondents, 381 indicated that they are either interested or very interested to participate in scientific research projects. This suggests that more than a third (36.2\%) of the Swiss population could be motivated to participate in CS (see Appendix).

But who are the $36.2 \%$ potential citizen scientists? Using linear regression including the explanatory factors outlined above (Table 2), we were able to explain $35.1 \%$ of people's willingness to participate in scientific research projects, i.e. in CS projects - a relatively high number for linear regression models in communication science (Reinard, 2006). First, several sociodemographic variables explain this willingness: people who are younger, have a higher proximity to science, and live in households with children $^{3}$ are more likely to be interested in participation in scientific research. Notably, however, the results do not indicate that respondents' gender, education level, employment status, religiosity or political orientation are relevant explanatory factors ${ }^{4}$.

Second, several attitudinal variables influence the willingness to participate in CS: peoples' interest in science, their feeling that science plays an important role in their life and their proneness to seek information about science - i.e. cognitive as well as affective and conative factors - show the strongest relations. Our analysis further suggests that neither respondents' scientific literacy nor their trust in science are relevant predictors of their willingness to participate in CS.

\footnotetext{
${ }^{3}$ We would like to emphasize that living in a household with children can also mean that the respondents themselves live with their parents. We reran the analysis for respondents older than 25 and discovered the same main effects (see Appendix). ${ }^{4}$ Political orientation was the variable that elicited by far the most amount of missing values. Seeing the insignificance of this predictor, we reran the analysis without people's political orientation and discovered the same main effects.
} 
RQ2: Among Swiss citizens interested to participate in CS, which segments can be differentiated?

Latent class analysis constructed five segments of respondents who are all interested in participating in citizen science (Table 3). The five segments differ clearly in their sociodemographic and sciencerelated characteristics and can be compared to respondents who were not willing to participate in citizens science and were excluded from segmentation analysis - called "non-CS" ( $n=670)$ from here on-:

Table 3: Segment variable means for the five-cluster solution as well as for people not interested in participating in CS.

\begin{tabular}{|c|c|c|c|c|c|c|}
\hline Segments $(N=1051)$ : & $\begin{array}{l}\text { Non-CS } \\
(63.75 \%)\end{array}$ & $\begin{array}{c}\text { Free-Tim- } \\
\text { ers } \\
(11.23 \%)\end{array}$ & $\begin{array}{c}\text { Senior } \\
\text { Science- } \\
\text { philes } \\
(8.47 \%)\end{array}$ & $\begin{array}{c}\text { Young } \\
\text { Science- } \\
\text { philes } \\
(4.09 \%)\end{array}$ & $\begin{array}{c}\text { Intrigued } \\
\text { Adoles- } \\
\text { cents } \\
(6.95 \%)\end{array}$ & $\begin{array}{c}\text { Fully } \\
\text { Employed } \\
\text { Parents } \\
(5.52 \%)\end{array}$ \\
\hline Age & 48.15 & 55.38 & 54.50 & 25.57 & 17.94 & 45.62 \\
\hline Female (\%) & $54.54 \%$ & $82.74 \%$ & $16.72 \%$ & $34.59 \%$ & $42.55 \%$ & $17.00 \%$ \\
\hline Tertiary Education (\%) & $39.29 \%$ & $43.91 \%$ & $89.33 \%$ & $62.90 \%$ & $2.09 \%$ & $54.27 \%$ \\
\hline Household with Children (\%) & $65.64 \%$ & $58.69 \%$ & $79.72 \%$ & $75.59 \%$ & $93.87 \%$ & $88.42 \%$ \\
\hline Full-time Work (\%) & $33.38 \%$ & $0.95 \%$ & $77.37 \%$ & $33.28 \%$ & $22.02 \%$ & $100.00 \%$ \\
\hline $\begin{array}{l}\text { Political Orientation } \\
\text { (left: } 1 \text {-7: right) }\end{array}$ & 3.66 & 3.70 & 3.61 & 3.31 & 3.37 & 3.91 \\
\hline Religiosity (1-5) & 2.83 & 2.95 & 2.40 & 1.83 & 2.43 & 2.47 \\
\hline Proximity to Science (0-4) & 1.34 & 1.53 & 2.89 & 3.32 & 1.38 & 1.62 \\
\hline Scientific Literacy (0-2) & 0.77 & 0.81 & 1.05 & 0.89 & 0.72 & 0.87 \\
\hline Trust in Science (1-5) & 3.48 & 3.68 & 3.87 & 4.19 & 3.67 & 3.46 \\
\hline Interest in Science (1-5) & 3.17 & 3.70 & 4.42 & 4.70 & 3.63 & 3.43 \\
\hline $\begin{array}{l}\text { Personal Life-Relevance of Science } \\
(1-5)\end{array}$ & 2.76 & 3.75 & 4.12 & 4.45 & 3.51 & 3.40 \\
\hline Science Information Seeking (1-5) & 2.78 & 3.41 & 4.24 & 4.28 & 3.56 & 3.37 \\
\hline
\end{tabular}

The "Free-Timers" $(n=118)$ form the largest segment, representing $11.2 \%$ of the Swiss population and $31 \%$ of those who would be willing to participate in CS. On average, they are 55 years old. They are mostly women (54.5\%), and, in stark contrast to all other groups, almost none of them (1\%) work full time. A closer look at their employment status reveals that this group mainly consists of people who are part-time employed (58.7\%), retired (20.2\%) or homemakers (13.1\%). Similar to all other CS groups, "Free-Timers" have significantly ${ }^{5}$ more positive cognitive, affective, and conative attitudes towards and trust in science (means ranging around 3.5) than the rest of the population. Their scientific literacy and proximity to science scores, however, do not significantly differ to the "Non-CS" group's. The remaining indicators like their education, political ideology, scientific literacy and proximity to science do not significantly differ to the rest of the population ("Non-CS").

The "Senior Sciencephiles" $(n=89)$ are the second largest group, consisting of $8.5 \%$ of our representative sample and represent $23.4 \%$ of those who would be willing to participate in CS. We named them "Sciencephiles" in reference to a group regularly described in science communication (Kawamoto et al., 2013; Schäfer et al., 2018): a part of the population that shows highly positive attitudes towards science (ranging around 4.2 ), is predominantly male (83.3\%) and tends to have higher than average

\footnotetext{
${ }^{5}$ We have run pairwise (Holm correction) t-tests regarding group means for each variable that was used to describe segments from here on out. We use $p<0.05$ significances as a mean to identify and describe the most striking segment differences. We abstained from depicting this information in tables and figures because they would become hard to read. But all pairwise comparisons for each variable can be found in the Appendix.
} 
proximity to science (2.89), trust in science (3.87), and scientific literacy (1.05). We use the term "senior" because this segment is 55 years on average and also because it has the largest share of people with tertiary education (89.3\%). The "Senior Sciencephiles" tend to live in households with children (79.7\%) and are likely working full-time jobs $(77,4 \%)$. They do not differ from the rest of the population (“Non-CS") concerning their political orientation but are significantly less religious.

As their name indicates, the "Young Sciencephiles" ( $n=43 ; 4.1 \%$ of population, $11.3 \%$ of those who are willing to participate in CS) are similar to their senior counterparts: they are mostly male (65.4\%) and do not display any significant differences regarding their positive attitudes towards science(around 4.2), trust in science (4.19) and proximity to science (3.32). Only their scientific literacy (0.89) is significantly lower than the "Senior's" while being significantly higher than all other groups'. The striking difference is, of course, their younger average age of 25.6 years. Generally, the "Young Sciencephiles"” have the lowest levels of religiosity (1.83), most left-leaning political orientation (3.31), are more educated (62.9\% tertiary) than the rest of the population ("Non-CS") and tend to have work arrangements that do not occupy them full-time (33.3\% work full-time, the rest is still undergoing education or works part-time).

The "Intrigued Adolescents" ( $n=73$ ) stand for $7 \%$ of the Swiss population and for $19.2 \%$ of those who would be willing to participate in CS. As our youngest group with about 18 years old, this set of respondents did not yet have an opportunity to acquire tertiary education $(2.1 \%)$ as $68 \%$ of them are still in school. These adolescents do not significantly differ from the "Non-CS" population with regards to their proximity to science (1.38), trust in science (3.67), or scientific literacy (0.72). However, they have significantly more positive attitudes towards science (around 3.5), similar to the "Free-Timers" but significantly lower than the two "Sciencephiles". While it might not be ideal to overemphasize political orientation for such a young respondents, the "Intrigued Adolescents" tend to have low levels of religiosity (2.47) and are the CS group with the best gender balance ( $42.6 \%$ women).

Representing $5.5 \%$ of the population and $15.2 \%$ of those willing to participate in CS, the "Fully Employed Parents" $(n=58)$ are a group with an average age of 45.8 years that predominantly consists of men (83\%) living in households with (most likely their) children (88.4\%) and working full-time exclusively (100\%). Their attitudes towards science match the ones of the "Free-Timers" and the "Intrigued Adolescents". The same is true for their trust in science (3.46), scientific literacy (0.87), and proximity to science (1.62), which also are on the same level as the "Non-CS" group.

RQ3: What are the best ways to address the segments with regards to their topical interests and commonly used communication channels?

The five segments of respondents willing to participate in CS show not only differences along the 13 variables used for clustering. They also differ in the specific fields of science they are interested in, and in the communication channels they regularly use to come in contact with science. These differences point to target-specific ways to address segments and improve recruitment success. 


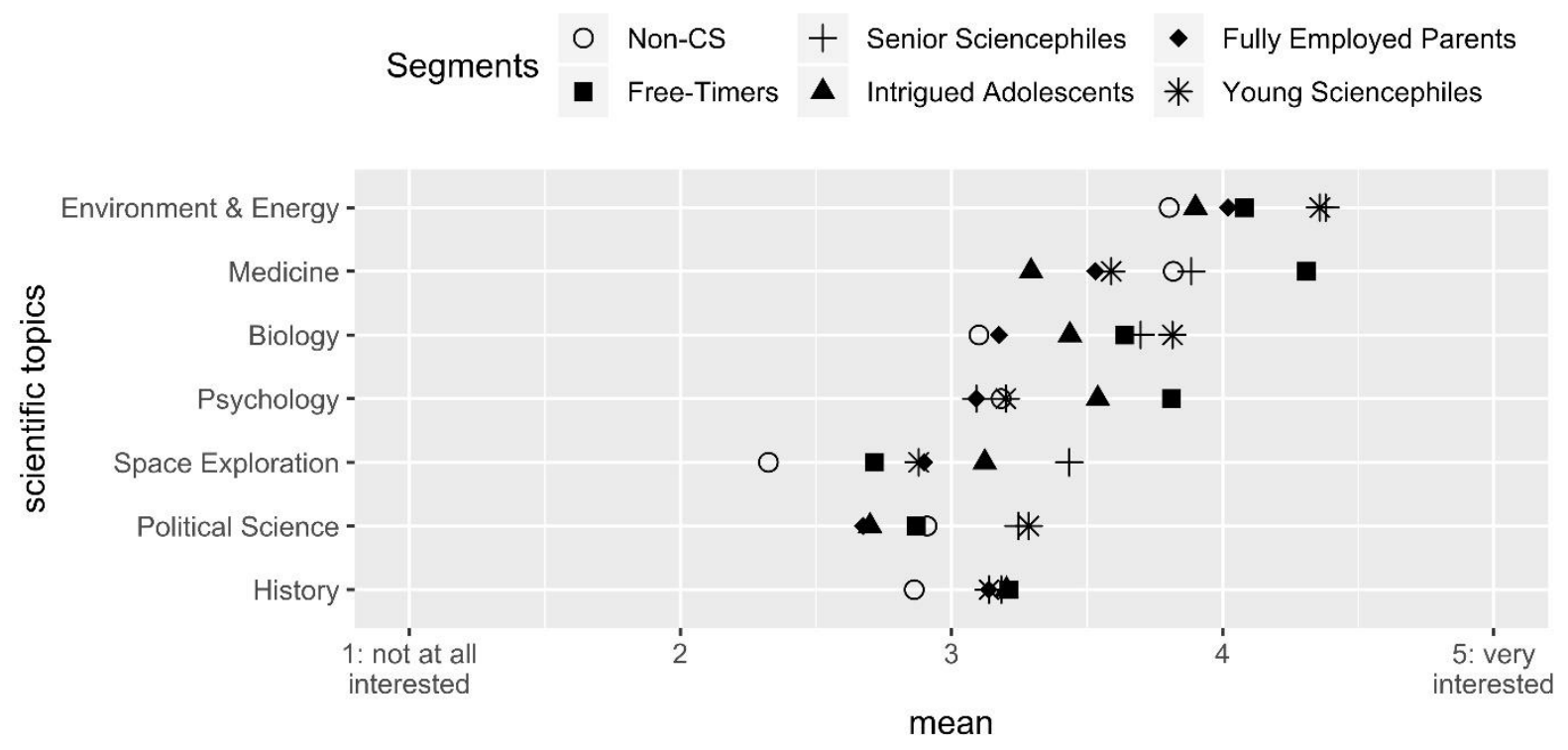

Figure 1 shows specific scientific topics that the five segments might be interested in. Overall, we see that environment \& energy and medicine are rated as the most interesting topics by almost all segments. The only exception are the "Young Sciencephiles", who prefer biology to medicine, and the "Intrigued Adolescents", who regard psychology as more interesting than medicine. Unsurprisingly, biology and psychology are also topics that all groups consider interesting (i.e. above 3.0 scale points). While it is not any segment's favourite, space exploration is the only topic where the rest of the population ("Non-CS") significantly trails behind all five CS segments' interest. 
Figure 2: Frequency of legacy media, online media, and alternative contact with science and research across population segments (descending means per category)
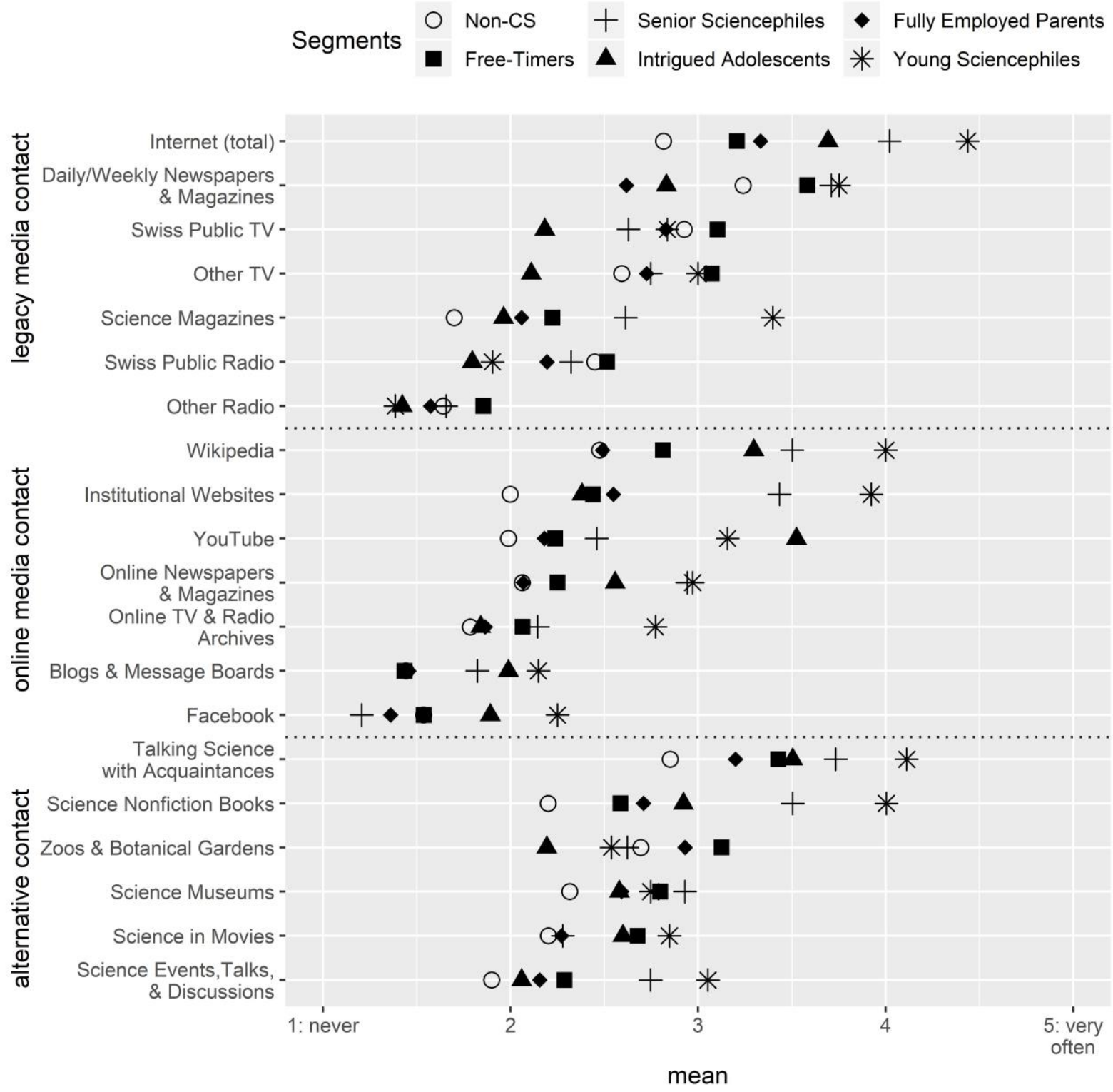

The top section of Figure 2 depicts the main legacy media information sources that people have available in Switzerland. Overall, we see that the segments do not greatly differ from the "Non-CS" population. The internet is the only source where all CS segments indicated significantly higher frequencies. Except for the "Free-Timers", who prefer newspapers, the internet is the most frequent source of the other four CS groups, followed by daily and weekly newspapers and magazines and Swiss public television. Furthermore, science magazines are the source that is most likely to reach a specific group, as the "Young Sciencephiles" read them significantly more often than any other group.

Segments show more pronounced differences across specific online sources, however (middle section of Figure 2). The "Young Sciencephiles" and the "Senior Sciencephiles" mostly frequent websites from official authorities and scientific institutions as well as Wikipedia entries, while the "Intrigued Adolescents" regularly come across scientific content on YouTube and Wikipedia. The "Free-Timers" and "Fully Employed Parents" have online contact with science and research on a level comparable with the "Non-CS" group. The only source where they have higher means are institutional websites; something which applies to all CS segments. 
A more likely way to reach "Free Timers" and "Fully Employed Parents" are alternative contact forms with science and research (bottom section of Figure 2). Group means suggest that these two groups are the two groups most likely to go to zoos and botanical gardens - although only the "Free-Timers" do so significantly more often than the rest of the population. Science-related books and talking about science with acquaintances are the two contact forms where all CS groups display significantly higher frequencies than the "Non-CS" group; both activities most likely done by the young and senior "Sciencephiles". To a lesser extent, science events, talks and discussions are places where people interested to participate in CS are more likely to be found than the rest of the population ("Non-CS"), with significantly higher values for the two "Sciencephiles" and the "Free-Timers".

\section{Discussion \& Conclusion}

The rise of CS is one of many phenomena that can be attributed to science and society moving closer together via proliferation of digital media (Dickel \& Franzen, 2016). CS projects offer academic output for scientists as well as genuine engagement with science for a potentially broad spectrum of participants. Accordingly, scholars have linked CS with the ideal of democratizing science through public participation in knowledge production (Hecker et al., 2018). While many projects are able to recruit many participants, however, they only seem to reach a certain part of the population that is mostly male, highly educated and scientifically literate, and already has highly favourable attitudes towards science (Curtis, 2018; Pandya \& Dibner, 2018). Current CS, it seems, does not yet come close to engaging a broad public. But it remains unclear whether future CS projects have the potential to reach a wider range of participants, what these participants look like and how they are likely to be reached and convinced to participate.

Our study looked beyond participants that had already signed up for CS projects. Based on a national representative survey, it measured the Swiss' interest in participating in scientific research projects. Results show that approximately one third of the population (36.2\%) are interested in participating in CS. This is a promising percentage compared to the $19.5 \%$ of the Swiss population that engage in institutionalised voluntary work ${ }^{6}$ in 2016 (Federal Statistical Office, 2019).

Linear regression analysis (Table 2) confirmed that people interested in participation tend to be associated with more positive attitudes towards science (cognitive, affective and conative) - and tend to have a social environment that is related to scientific research. This suggests that potential citizen scientists are very likely to have a favourable outlook on science and scientific research to begin with, and that the CS is mostly found in a science-interested subset of the population.

Further results, however, go against conclusions drawn from participant samples: neither people's gender, tertiary education nor scientific literacy are relevant predictors for people's interest in participating in scientific research projects. Moreover, our regression model shows that having children in one's household has a significant relation with people's interest in CS. All of these findings make clear that CS projects do have the initial potential to recruit a more diverse set of participants that goes beyond a group of highly educated men. As a novel insight, our data suggests that family households might be a worthwhile target of recruitment in general. Future studies might try to dive deeper and find out whether people who live in households with children would be interested in "Family Citizen Science" or whether they are more interested in CS as an activity to "take a break" from family life.

Beyond general characteristics of potential citizen scientists, we identified five population segments (Table 3) among people that declared an interest in participating in scientific research projects $(\mathrm{N}=381)$.

\footnotetext{
${ }^{6}$ Defined as voluntary work that goes beyond helping friends and family, e.g. political engagement or helping a local sports club.
} 
As predicted by the regression analysis, all segments are characterised by positive to very positive attitudes towards science. On the one hand, we find the "Senior and Young Sciencephiles" who are reminiscent of typical CS participants. On the other hand, we reconstructed three segments that have been underrepresented in CS projects so far: the "Free-Timers" mostly consist of women and have more leisure time at their disposal; the "Intrigued Adolescents" are the youngest group, are not highly educated (yet), and have a proximity to science similarly low as to the rest of the Swiss population; lastly, the "Fully Employed Parents" work in full time jobs, and are highly likely to have children at home.

Since only two of five segments resemble participants that have been represented in recorded CS projects, however, it is important to analyse how other groups can be reached and addressed. Our results show that potential citizen scientists are most interest medicine and environmental and energy issues, but also that the "Free-Timers" would be more interested in medicine-related projects while the four other segments are a better fit for environment-related issues. We also see that topics like history and political science are only slightly more popular amongst CS segments than across the rest of the population (i.e. the "Non-CS" group) and might make for projects that find it more difficult to acquire participants.

Looking at journalistic news media and online sources, we see that it might be challenging to reach the three underrepresented CS segments in the first place. The "Young and Senior Sciencephiles" are most frequently exposed to science on almost all the channels; the internet, more specifically institutional websites and Wikipedia, being the most pronounced source. Project organisers who want to reach other potential participants might have to take advantage of other communication forms. For example, "Intrigued Adolescents" often encounter science on YouTube, which offers the possibilities of video or targeted ad campaigns. "Free Timers" and "Fully Employed Parents", on the other hand, are the two groups significantly most likely to go to, and therefore be reached in, zoos and botanical gardens (mean frequency around 3). A hidden feature of all groups is that they frequently talk about science with their friends and family, increasing the chance of organic word of mouth campaigning.

\section{Implications \& Limitations}

Our study implies that CS projects have a significantly more diverse pool of potential participants than they were previously able to motivate. This finding is limited by the fact that our item asked about "participating scientific research" rather than naming "citizen science" directly. We chose this wording because the Swiss public would not have been familiar with the term "citizen science". The question remains whether the respondents were thinking about something similar to CS or whether they have other forms of participation concretely in mind at all - this cannot be clarified with our data. Our findings can be somewhat corroborated by the German Science Barometer, which clearly asked about citizen science, used the term itself, and also found that $30 \%$ would like to participate, with a distribution similar to the Swiss one (Wissenschaft im Dialog, 2014).

We also would like to point out that our unique perspective only sheds light on one specific step of potential participation in CS projects - at peoples' initial interest. While behavioural intentions have proven to be strong predictors of actual behaviour (Ajzen, 2011), there will still be a large number of "inclined abstainers" who say they want to participate but never do (Sniehotta, Presseau, \& AraújoSoares, 2014, p. 2). This is not surprising as the chain of actions from interest to participate to prolonged participation is long and complex (Weitkamp, 2016). For example, we do not know which kind of project our potential citizen scientists would want to be part of, whether they have participated in CS before, or what kind of tasks they would be willing to do (Shirk et al., 2012). In addition, once people have started participation, their motivations become diverse and key factors in maintaining participation and affecting outcomes like knowledge and attitudes (Jennett et al., 2016). Future studies that can work with representative data sets should aim to include more variables than just one item 
measures of people's basic interest in CS and include specific questions about prior participation and interest in project types, tasks and topics.

The large variability in segment characteristics highlights that general interpretations of the regression model are helpful for a relative description of factors but do not tell us much about actual characteristics of potential citizen scientists. For example, proximity to science was a significantly positive predictor but there are still specific groups like the "Free-Timers" and "Young Adolescents" with an average proximity to science. The small but significant correlation of people's age does also not directly translate to our segments who display a broad range of mean ages. We think that regression models are worthwhile as future research can parse out whether there are more universal predictors for people's willingness to participate in CS. If project organisers have access to their country specific data though, it will be more effective to focus on tailored segmentation analyses.

Future CS scholarship could benefit from research on volunteering: It would be interesting to assess CS participation rates and compare them to voluntary engagement rates in sectors like sports, culture and education (Simonson, Ziegelmann, Vogel, \& Tesch-Römer, 2017). Additionally, the catalogue of motives developed in research on (maintained) volunteering could be incorporated in CS research (Müller, Hameister, \& Lux, 2017). For example, the role of monetary incentives has not been empirically considered in CS research yet (Hecker et al., 2018).

When it comes to the potential of CS to enable public and open knowledge production, is not enough to know which people to reach through which communication channels for which project type and how to motivate them to participate. While this was outside of the scope of our study, it would be worthwhile to investigate the gap we discovered between groups interested in CS and groups actually reported in CS projects. Concepts like cultural capital and threshold fear might offer an interesting perspective for such investigations as they describe how certain groups like women and less educated people might still ultimately refrain from actually participating in research projects due to cultural forces (Curtis, 2018). Only if these aspects receive significantly more attention, the full potential of CS can be unlocked. 


\section{References}

Ajzen, I. (2011). The theory of planned behaviour: Reactions and reflections. Psychology \& Health, 26(9), 1113-1127. https://doi.org/10.1080/08870446.2011.613995

Alender, B. (2016). Understanding volunteer motivations to participate in citizen science projects: A deeper look at water quality monitoring. Journal of Science Communication, 15(03). https://doi.org/10.22323/2.15030204

Bauer, M. W. (2016). The Culture of Science Indicators. London: LSE.

Besley, J. C. (2013). The State of Public Opinion Research on Attitudes and Understanding of Science and Technology. Bulletin of Science, Technology \& Society, 33(1-2), 12-20. https://doi.org/10.1177/0270467613496723

Besley, J. C. (2018). Audiences for Science Communication in the United States. Environmental Communication, 112, 1-18. https://doi.org/10.1080/17524032.2018.1457067

Bonney, R., Ballard, Heidi, Jordan, R., McCallie, E., Phillips, Tina, Shirk, Jennifer, \& Wilderman, C. C. (2009). Public Participation in Scientific Research: Defining the Field and Assessing Its Potential for Informal Science Education. Washington, DC. Retrieved from http://files.eric.ed.gov/fulltext/ED519688.pdf

Bonney, R., Phillips, Tina B., Ballard, Heidi L., \& Enck, J. W. (2016). Can citizen science enhance public understanding of science? Public Understanding of Science (Bristol, England), 25(1), 2-16. https://doi.org/10.1177/0963662515607406

Burgess, H. K., DeBey, L. B., Froehlich, H. E., Schmidt, N., Theobald, E. J., Ettinger, A. K., . . Parrish, J. K. (2017). The science of citizen science: Exploring barriers to use as a primary research tool. Biological Conservation, 208, 113-120. https://doi.org/10.1016/j.biocon.2016.05.014

Chapman, C., \& Feit, E. M. (2015). $R$ for marketing research and analytics: Springer.

Curtis, V. (2018). Online Citizen Science and the Widening of Academia. Cham: Springer International Publishing.

Dean, A. J., Church, E. K., Loder, J., Fielding, K. S., \& Wilson, K. A. (2018). How do marine and coastal citizen science experiences foster environmental engagement? Journal of Environmental Management, 213, 409-416. https://doi.org/10.1016/i.jenvman.2018.02.080

Dickel, S., \& Franzen, M. (2016). The "Problem of Extension" revisited: New modes of digital participation in science. Journal of Science Communication, 15(01). https://doi.org/10.22323/2.15010206

Eurobarometer, S. (2005). Europeans, Science and Technology.

Fähnrich, B., Janssen Danyi, C., \& Nothhaft, H. (2015). The German plagiarism crisis. Journal of Communication Management, 19(1), 20-38. https://doi.org/10.1108/JCOM-11-2013-0081

Federal Statistical Office. (2019). Freiwilligenarbeit [voluntary work]: Beteiligung der Bevölkerung in \% [public participation in \%]. Retrieved from https://www.bfs.admin.ch/bfs/de/home/statistiken/arbeit-erwerb/unbezahlte-arbeit/freiwilligenarbeit.html

Gibbons, M., Limoges, C., Nowotny, H., Schwartzman, S., Scott, P., \& Trow, M. (1994). The new production of knowledge: The dynamics of science and research in contemporary societies. London: Sage Publications.

Gollwitzer, M. (2012). Latent-Class-Analysis. In H. Moosbrugger \& A. Kelava (Eds.), Testtheorie und Fragebogenkonstruktion (pp. 295-323). Berlin, Heidelberg: Springer Berlin Heidelberg.

Haklay, M. (2018). Participatory citizen science. In S. Hecker, M. Haklay, A. Bowser, Z. Makuch, J. Vogel, \& A. Bonn (Eds.), Citizen Science: Innovation in Open Science, Society and Policy (pp. 52-62). London: UCL Press. 
Hecker, S., Haklay, M., Bowser, A., Makuch, Z., Vogel, J., \& Bonn, A. (Eds.). (2018). Citizen Science: Innovation in Open Science, Society and Policy. London: UCL Press.

Irwin, A. (1995). Citizen Science: A Study of People, Expertise and Sustainable Development. London: Routledge.

Jennett, C., Kloetzer, L., Schneider, D., lacovides, I., Cox, A., Gold, M., ... Talsi, Y. (2016). Motivations, learning and creativity in online citizen science. Journal of Science Communication, 15(03). https://doi.org/10.22323/2.15030205

Kawamoto, S., Nakayama, M., \& Saijo, M. (2013). A survey of scientific literacy to provide a foundation for designing science communication in Japan. Public Understanding of Science (Bristol, England), 22(6), 674-690. https://doi.org/10.1177/0963662511418893

Kullenberg, C., \& Kasperowski, D. (2016). What Is Citizen Science?--A Scientometric Meta-Analysis. PloS One, 11(1), e0147152. https://doi.org/10.1371/journal.pone.0147152

Land-Zandstra, A. M., Devilee, J. L. A., Snik, F., Buurmeijer, F., \& van den Broek, J. M. (2016). Citizen science on a smartphone: Participants' motivations and learning. Public Understanding of Science (Bristol, England), 25(1), 45-60. https://doi.org/10.1177/0963662515602406

Lee, C.-J., Scheufele, D. A., \& Lewenstein, Bruce V. (2005). Public Attitudes toward Emerging Technologies. Science Communication, 27(2), 240-267. https://doi.org/10.1177/1075547005281474

Lewenstein, Bruce. (2016). Can we understand citizen science? Journal of Science Communication, 15(01). https://doi.org/10.22323/2.15010501

Lüdecke, D. (2018). sjPlot. Retrieved from https://CRAN.R-project.org/package=sjPlot

Lynch, L. I., Dauer, J. M., Babchuk, W. A., Heng-Moss, T., \& Golick, D. (2018). In Their Own Words: The Significance of Participant Perceptions in Assessing Entomology Citizen Science Learning Outcomes Using a Mixed Methods Approach. Insects, 9(1). https://doi.org/10.3390/insects9010016

Martin, V. Y. (2017). Citizen Science as a Means for Increasing Public Engagement in Science. Science Communication, 39(2), 142-168. https://doi.org/10.1177/1075547017696165

Miller, J. D. (1983). Scientific Literacy: A Conceptual and Empirical Review. Daedalus, 112(2), 29-48. Retrieved from http://www.jstor.org/stable/20024852

Miller-Rushing, A., Primack, R., \& Bonney, R. (2012). The history of public participation in ecological research. Frontiers in Ecology and the Environment, 10(6), 285-290. https://doi.org/10.1890/110278

Müller, D., Hameister, N., \& Lux, K. (2017). Anstoß und Motive für das freiwillige Engagement [initiation and motives for voluntary engagement]. In J. Simonson, C. Vogel, \& C. Tesch-Römer (Eds.), Freiwilliges Engagement in Deutschland [voluntary engagement in Germany] (pp. 413-435). Wiesbaden: Springer Fachmedien Wiesbaden.

Nature. (2015). Rise of the citizen scientist. Nature, 524(7565), 265. https://doi.org/10.1038/524265a

Nowotny, H., Scott, P., \& Gibbons, M. (2001). Re-thinking science: Knowledge and the public in an age of uncertainty. Cambridge: Polity Press.

Pandya, R., \& Dibner, K. A. (2018). Learning Through Citizen Science: Enhancing Opportunities by Design. Washington, D.C.: National Academies Press.

Pardo, R., \& Calvo, F. (2002). Attitudes toward science among the European public: A methodological analysis. Public Understanding of Science, 11(2), 155-195. https://doi.org/10.1088/0963$6625 / 11 / 2 / 305$

Pardo, R., \& Calvo, F. (2004). The Cognitive Dimension of Public Perceptions of Science: Methodological Issues. Public Understanding of Science, 13(3), 203-227. https://doi.org/10.1177/0963662504045002 
Penner, L. A. (2002). Dispositional and Organizational Influences on Sustained Volunteerism: An Interactionist Perspective. Journal of Social Issues, 58(3), 447-467. https://doi.org/10.1111/15404560.00270

Reinard, J. C. (2006). Communication research statistics. Thousand Oaks, Calif: Sage Publications. Retrieved from http://www.loc.gov/catdir/enhancements/fy0658/2005020161-d.html

Runge, K. K., Brossard, D., \& Xenos, M. A. (2018). Protective Progressives to Distrustful Traditionalists: A Post Hoc Segmentation Method for Science Communication. Environmental Communication, 21(1), 1-23. https://doi.org/10.1080/17524032.2018.1513854

Schäfer, M. S., Füchslin, T., Metag, J., Kristiansen, S., \& Rauchfleisch, A. (2018). The different audiences of science communication: A segmentation analysis of the Swiss population's perceptions of science and their information and media use patterns. Public Understanding of Science (Bristol, England), 27(7), 836-856. https://doi.org/10.1177/0963662517752886

Schäfer, M. S., Metag, J., Feustle, J., \& Herzog, L. (2016). Selling science 2.0: What scientific projects receive crowdfunding online? Public Understanding of Science (Bristol, England), 27(5), 496-514. https://doi.org/10.1177/0963662516668771

Science et Cité. (2015). Citizen Science in der Schweiz: Situationsanalyse und Zukunftsperspektiven. Retrieved from https://www.science-et-cite.ch/docs/projekte/150130 CitizenScienceSchweiz VersandNetzwerk.pdf

SciStarter. (2018). Project Finder. Retrieved from https://scistarter.com/finder

Shirk, Jennifer L., Ballard, Heidi L., Wilderman, C. C., Phillips, Tina, Wiggins, A., Jordan, R., . . Bonney, R. (2012). Public Participation in Scientific Research: A Framework for Deliberate Design. Ecology and Society, 17(2). https://doi.org/10.5751/ES-04705-170229

Simonson, J., Ziegelmann, J. P., Vogel, C., \& Tesch-Römer, C. (2017). Zentrale ergebnisse des Deutschen Freiwilligensurveys 2014 [key findings of the German voluntary engagement survey 2014]. In J. Simonson, C. Vogel, \& C. Tesch-Römer (Eds.), Freiwilliges Engagement in Deutschland [voluntary engagement in Germany] (pp. 21-27). Wiesbaden: Springer Fachmedien Wiesbaden.

Sniehotta, F. F., Presseau, J., \& Araújo-Soares, V. (2014). Time to retire the theory of planned behaviour. Health Psychology Review, 8(1), 1-7. https://doi.org/10.1080/17437199.2013.869710

Taddicken, M., Reif, A., \& Hoppe, I. (2018). What do people know about climate change - and how confident are they?: On measurements and analyses of science related knowledge. Journal of Science Communication, 17(03). https://doi.org/10.22323/2.17030201

Vermunt, J. K., \& Magidson, J. (2016). Technical guide for Latent GOLD 5.1: Basic, advanced, and syntax. Retrieved from https://www.statisticalinnovations.com/wp-content/uploads/LGtecnical.pdf

Weingart, P. (2001). Die Stunde der Wahrheit? [The Moment ofTruth?]: Zum Verhältnis der Wissenschaft zu Politik, Wirtschaft und Medien in der Wissensgesellschaft [On Science's Relationship with Politics, Economics, and the Media in the Knowledge Society ] (1. Aufl.). Weilerswist: Velbrück Wiss. Retrieved from http://hsozkult.geschichte.hu-berlin.de/rezensionen/type=rezbuecher\&id=768

Weitkamp, E. (2016). From planning to motivations: Citizen science comes to life. Journal of Science Communication, 15(03). https://doi.org/10.22323/2.15030501

West, S., \& Pateman, R. (2016). Recruiting and Retaining Participants in Citizen Science: What Can Be Learned from the Volunteering Literature? Citizen Science: Theory and Practice, 1(2), 197. https://doi.org/10.5334/cstp.8

Wissenschaft im Dialog. (2014). Wissenschaftsbarometer 2014 [Science Barometer 2014]. Retrieved from https://www.wissenschaft-im-dialog.de/projekte/wissenschaftsbarometer/wissenschaftsbarometer-2014/ 
Wissenschaft im Dialog. (2015). Wissenschaftsbarometer 2015 [Science Barometer 2015]. Retrieved from http://www.wissenschaft-im-dialog.de/projekte/wissenschaftsbarometer/

Zavestoski, S., Shulman, S., \& Schlosberg, D. (2016). Democracy and the Environment on the Internet. Science, Technology, \& Human Values, 31(4), 383-408. https://doi.org/10.1177/0162243906287543 


\section{Appendix}

Distribution of people's interest to participate in scientific research projects

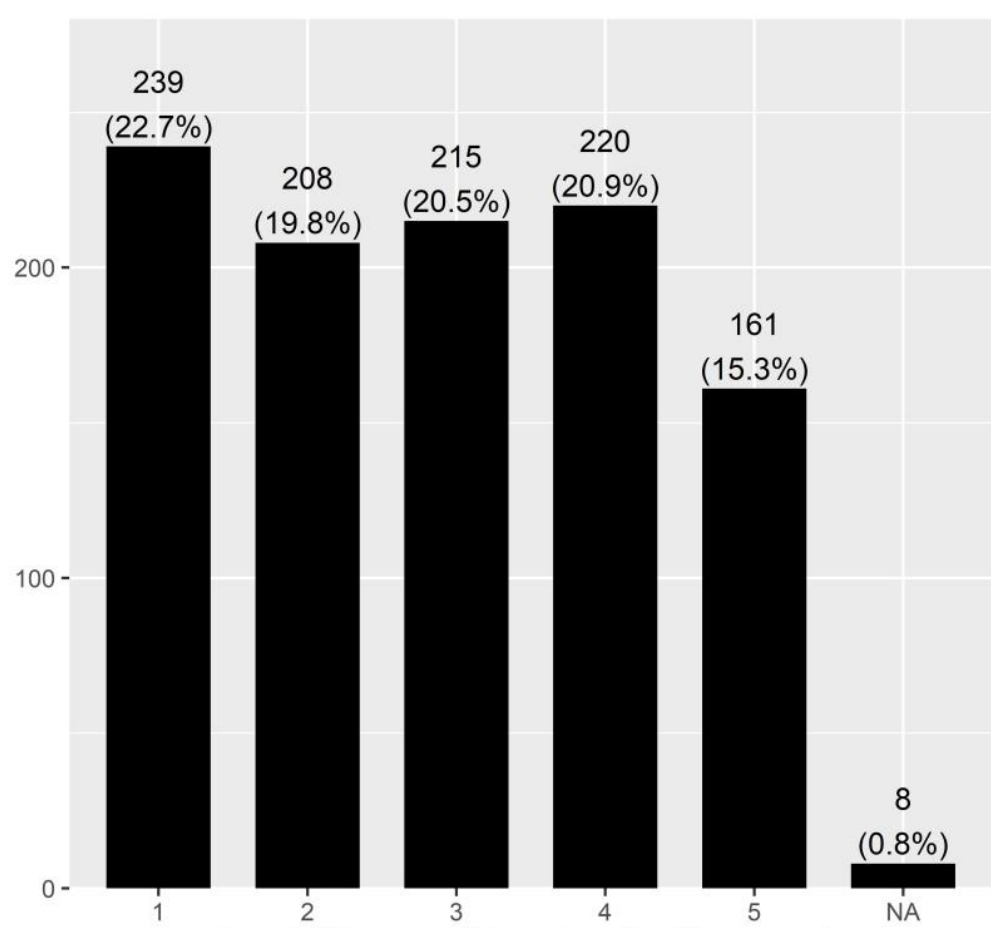

I would like to participate in scientific research projects (once) $(\mathrm{N}=1051)$

Regression model for respondents older than 25 years

\begin{tabular}{lccc}
\hline \hline & \multicolumn{3}{c}{ DV: „I would like to participate in scientific re- } \\
search projects (once) & \\
Explanatory Variables & Std. Betas & $C l$ & $p$ \\
\hline (Intercept) & -0.05 & $-0.11-0.01$ & 0.121 \\
Age & -0.06 & $-0.15-0.03$ & 0.219 \\
Female & 0.02 & $-0.05-0.09$ & 0.652 \\
Tertiary Education & 0.04 & $-0.02-0.11$ & 0.191 \\
Household with Children & 0.10 & $0.04-0.16$ & 0.001 \\
Full-time Work & 0.03 & $-0.04-0.10$ & 0.351 \\
Political Orientation (left:1-7:right) & 0.01 & $-0.05-0.07$ & 0.778 \\
Religiosity (1-5) & -0.02 & $-0.08-0.04$ & 0.505 \\
Proximity to Science (0-4) & 0.06 & $-0.01-0.13$ & 0.077 \\
Scientific Literacy (0-2) & 0.01 & $-0.05-0.08$ & 0.730 \\
Trust in Science (1-5) & 0.03 & $-0.04-0.09$ & 0.416 \\
Interest in Science (1-5) & 0.14 & $0.07-0.21$ & $<0.001$ \\
Personal Life-Relevance of Science & 0.35 & $0.28-0.42$ & $<0.001$ \\
(1-5) & & & \\
Science Information Seeking (1-5) & 0.11 & $0.03-0.18$ & 0.004 \\
\hline Observations & 779 & & \\
R $^{2} /$ adjusted R & $0.339 / 0.328$ &
\end{tabular}


LatentGold 5.1 Syntax Specifications

options

maxthreads $=8$

algorithm

tolerance $=1 \mathrm{e}-008$ emtolerance $=0.01$ emiterations $=250$ nriterations $=50$;

startvalues

seed $=0$ sets $=5000$ tolerance $=1 \mathrm{e}-005$ iterations $=50$;

bayes

categorical $=1$ variances $=1$ latent $=1$ poisson $=1$

montecarlo

seed $=0$ set $=0$ replicates $=500$ tolerance $=1 \mathrm{e}-008$;

quadrature nodes $=10$;

missing includeall;

output

parameters=effect betaopts=wl standarderrors=robust profile probmeans=posterior bivariateresiduals classification estimatedvalues=model

BIC values

BIC values of $L C A$ solutions

\begin{tabular}{|l|l|}
\hline BICs & Number of Segments \\
\hline 13220.7658 & 1 \\
\hline 13016.2247 & 2 \\
\hline 12869.4015 & 3 \\
\hline 12846.3074 & 4 \\
\hline 12827.1006 & 5 \\
\hline 12838.7216 & 6 \\
\hline 12874.7154 & 7 \\
\hline 12913.3271 & 8 \\
\hline
\end{tabular}


Pairwise t-tests

Comparison 1: Segmentation Variables

\section{Age}

Free-Timers

Senior Sciencephiles

Intrigued Adolescents

Fully Employed Parents

Young Sciencephiles

\section{Female}

Free-Timers

Senior Sciencephiles

Intrigued Adolescents

Fully Employed Parents

Young Sciencephiles

Tertiary Education

Free-Timers

Senior Sciencephiles

Intrigued Adolescents

Fully Employed Parents

Young Sciencephiles

\section{Household with Children}

Free-Timers

Senior Sciencephiles

Intrigued Adolescents

Fully Employed Parents

Young Sciencephiles

\section{Fulltimework}

Free-Timers

Senior Sciencephiles

Intrigued Adolescents

Fully Employed Parents

Young Sciencephiles

\section{PolRight}

Free-Timers

1.00

Senior Sciencephiles

Intrigued Adolescents

Fully Employed Parents

Young Sciencephiles

0.69

1.00

0.45

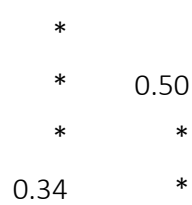

*

* $\quad 0.50$

0.34

Timers Sciencephiles

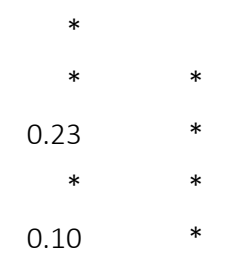

0.98

0.10

0.98

0.08

$0.40 \quad 0.69$

* $\quad 0.08$

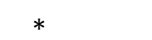

* $\quad *$

0.44

1.00

1.00

0.29

1.00

0.49

1.00
Fully Employed

Parents

$1.00 \quad 1.00$

$1.00 \quad 0.53$

1.00

$1.00 \quad 1.00$

0.90

$0.90 \quad 0.29$

1.00 


\begin{tabular}{|c|c|c|c|c|c|}
\hline Religious & $\begin{array}{l}\text { Non- } \\
\text { CS }\end{array}$ & $\begin{array}{l}\text { Free- } \\
\text { Timers }\end{array}$ & $\begin{array}{l}\text { Senior } \\
\text { Sciencephiles }\end{array}$ & $\begin{array}{l}\text { Intrigued } \\
\text { Adolescents }\end{array}$ & $\begin{array}{l}\text { Fully Employed } \\
\text { Parents }\end{array}$ \\
\hline Free-Timers & 0.52 & & & & \\
\hline Senior Sciencephiles & $*$ & $*$ & & & \\
\hline Intrigued Adolescents & 0.13 & * & 1.00 & & \\
\hline Fully Employed Parents & 0.26 & 0.09 & 1.00 & 1.00 & \\
\hline Young Sciencephiles & $*$ & $*$ & 0.26 & 0.17 & 0.16 \\
\hline \multicolumn{6}{|l|}{ SciProximity } \\
\hline Free-Timers & 1.00 & & & & \\
\hline Senior Sciencephiles & $*$ & $*$ & & & \\
\hline Intrigued Adolescents & 1.00 & 1.00 & $*$ & & \\
\hline Fully Employed Parents & 0.98 & 1.00 & $*$ & 1.00 & \\
\hline Young Sciencephiles & $*$ & $*$ & 0.98 & $*$ & $*$ \\
\hline \multicolumn{6}{|l|}{ Scilit } \\
\hline Free-Timers & 1.00 & & & & \\
\hline Senior Sciencephiles & $*$ & $*$ & & & \\
\hline Intrigued Adolescents & 1.00 & 1.00 & $*$ & & \\
\hline Fully Employed Parents & 1.00 & 1.00 & $*$ & 1.00 & \\
\hline Young Sciencephiles & $*$ & $*$ & $*$ & $*$ & * \\
\hline \multicolumn{6}{|l|}{ SciTrust } \\
\hline Free-Timers & $*$ & & & & \\
\hline Senior Sciencephiles & $*$ & 0.43 & & & \\
\hline Intrigued Adolescents & 0.12 & 1.00 & 0.60 & & \\
\hline Fully Employed Parents & 1.00 & 0.60 & $*$ & 0.60 & \\
\hline Young Sciencephiles & $*$ & $*$ & 0.43 & $*$ & $*$ \\
\hline \multicolumn{6}{|l|}{ Scilnterest } \\
\hline Free-Timers & $*$ & & & & \\
\hline Senior Sciencephiles & $*$ & $*$ & & & \\
\hline Intrigued Adolescents & $*$ & 0.57 & $*$ & & \\
\hline Fully Employed Parents & 0.23 & 0.31 & $*$ & 0.63 & \\
\hline Young Sciencephiles & $*$ & $*$ & 0.57 & $*$ & $*$ \\
\hline \multicolumn{6}{|l|}{ ScilmpForLife } \\
\hline Free-Timers & $*$ & & & & \\
\hline Senior Sciencephiles & $*$ & 0.08 & & & \\
\hline Intrigued Adolescents & $*$ & 0.35 & * & & \\
\hline Fully Employed Parents & $*$ & 0.19 & * & 0.58 & \\
\hline Young Sciencephiles & $*$ & * & 0.35 & $*$ & $*$ \\
\hline \multicolumn{6}{|l|}{ ScilnfoSeek } \\
\hline Free-Timers & $*$ & & & & \\
\hline Senior Sciencephiles & $*$ & * & & & \\
\hline Intrigued Adolescents & $*$ & 1.00 & $*$ & & \\
\hline Fully Employed Parents & $*$ & 1.00 & $*$ & 1.00 & \\
\hline Young Sciencephiles & $*$ & $*$ & 1.00 & $*$ & $*$ \\
\hline
\end{tabular}




\begin{tabular}{|c|c|c|c|c|c|}
\hline Medicine & Non-CS & $\begin{array}{l}\text { Free- } \\
\text { Timers }\end{array}$ & $\begin{array}{l}\text { Senior } \\
\text { Sciencephiles }\end{array}$ & $\begin{array}{l}\text { Intrigued } \\
\text { Adolescents }\end{array}$ & $\begin{array}{l}\text { Fully Employed } \\
\text { Parents }\end{array}$ \\
\hline Free-Timers & $*$ & & & & \\
\hline Senior Sciencephiles & 1.00 & $*$ & & & \\
\hline Intrigued Adolescents & $*$ & $*$ & $*$ & & \\
\hline Fully Employed Parents & 0.13 & $*$ & 0.14 & 1.00 & \\
\hline Young Sciencephiles & 1.00 & $*$ & 1.00 & 0.46 & 1.00 \\
\hline \multicolumn{6}{|l|}{ Environment \& Energy } \\
\hline Free-Timers & * & & & & \\
\hline Senior Sciencephiles & $*$ & 0.28 & & & \\
\hline Intrigued Adolescents & 1.00 & 1.00 & $*$ & & \\
\hline Fully Employed Parents & 0.35 & 1.00 & 0.56 & 1.00 & \\
\hline Young Sciencephiles & $*$ & 1.00 & 1.00 & 0.26 & 1.00 \\
\hline
\end{tabular}

\section{Biology}

Free-Timers

Senior Sciencephiles

Intrigued Adolescents

Fully Employed Parents

0.07

0.92

Young Sciencephiles

1.00

0.90

* $\quad 1.00$

Space Exploration

Free-Timers

Senior Sciencephiles

Intrigued Adolescents

Fully Employed Parents

0.57

1.00

* $\quad 1.00$

0.57

1.00

Young Sciencephiles

* $\quad 1.00$

0.58

Political Science

Free-Timers

Senior Sciencephiles

0.47

0.74

Intrigued Adolescents

1.00

1.00

0.48

Fully Employed Parents

1.00

1.00

0.16

1.00

Young Sciencephiles

0.53

0.74

1.00

0.48

\section{Psychology}

Free-Timers

Senior Sciencephiles

1.00

Intrigued Adolescents

0.32

0.58

0.17

Fully Employed Parents

1.00

1.00

0.60

Young Sciencephiles

1.00

0.06

1.00

1.00

1.00

\section{History}

Free-Timers

Senior Sciencephiles

Intrigued Adolescents

$0.78 \quad 1.00$

$0.61 \quad 1.00$

1.00

Fully Employed Parents

$0.78 \quad 1.00$

1.00

1.00

Young Sciencephiles

$1.00 \quad 1.00$

1.00

1.00

1.00 


\begin{tabular}{|c|c|c|c|c|c|}
\hline Swiss Public TV & Non-CS & $\begin{array}{l}\text { Free- } \\
\text { Timers }\end{array}$ & $\begin{array}{l}\text { Senior } \\
\text { Sciencephiles }\end{array}$ & $\begin{array}{l}\text { Intrigued } \\
\text { Adolescents }\end{array}$ & $\begin{array}{l}\text { Fully Employed } \\
\text { Parents }\end{array}$ \\
\hline Free-Timers & 0.49 & & & & \\
\hline Senior Sciencephiles & 0.36 & $*$ & & & \\
\hline Intrigued Adolescents & $*$ & $*$ & 0.49 & & \\
\hline Fully Employed Parents & 1.00 & 1.00 & 1.00 & . & \\
\hline Young Sciencephiles & 1.00 & 1.00 & 1.00 & * & 1.0 \\
\hline
\end{tabular}

\section{Other TV}

Free-Timers

Senior Sciencephiles

$0.68 \quad 0.34$

Intrigued Adolescents

0.11

Fully Employed Parents

\section{Swiss Public Radio}

Free-Timers

Senior Sciencephiles

\section{Other Radio}

Free-Timers

0.76

Senior Sciencephiles

Intrigued Adolescents

1.00

1.00

1.00

Fully Employed Parents

$1.00 \quad 1.00$

$1.00 \quad 1.00$

1.00

Young Sciencephiles

Newspapers \& Magazines

Free-Timers

0.08

Senior Sciencephiles

Intrigued Adolescents

Fully Employed Parents

Young Sciencephiles

\section{Science Magazines}

Free-Timers

Senior Sciencephiles

Intrigued Adolescents

Fully Employed Parents

Young Sciencephiles

\section{Internet}

Free-Timers

Senior Sciencephiles

Intrigued Adolescents

Fully Employed Parents

Young Sciencephiles

$\begin{array}{rr}* & 1.00 \\ 0.18 & * \\ * & * \\ 0.08 & 1.00\end{array}$

1.00

1.00

0.11

0.79

$0.14 \quad 0.69$

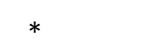

$*$




\begin{tabular}{|c|c|c|c|c|c|}
\hline Online News & Non-CS & $\begin{array}{l}\text { Free- } \\
\text { Timers }\end{array}$ & $\begin{array}{l}\text { Senior } \\
\text { Sciencephiles }\end{array}$ & $\begin{array}{l}\text { Intrigued } \\
\text { Adolescents }\end{array}$ & $\begin{array}{l}\text { Fully Employed } \\
\text { Parents }\end{array}$ \\
\hline Free-Timers & 0.78 & & & & \\
\hline Senior Sciencephiles & * & * & & & \\
\hline Intrigued Adolescents & $*$ & 0.44 & 0.66 & & \\
\hline Fully Employed Parents & 1.00 & 1.00 & * & 0.44 & \\
\hline Young Sciencephiles & * & $*$ & 1.00 & 0.28 & * \\
\hline \multicolumn{6}{|l|}{ Media Libraries } \\
\hline Free-Timers & 0.06 & & & & \\
\hline Senior Sciencephiles & * & 1.00 & & & \\
\hline Intrigued Adolescents & 1.00 & 1.00 & 1.00 & & \\
\hline Fully Employed Parents & 1.00 & 1.00 & 1.00 & 1.00 & \\
\hline Young Sciencephiles & * & $*$ & * & * & * \\
\hline \multicolumn{6}{|l|}{ Institutio I Websites } \\
\hline Free-Timers & * & & & & \\
\hline Senior Sciencephiles & * & $*$ & & & \\
\hline Intrigued Adolescents & * & 1.00 & * & & \\
\hline Fully Employed Parents & * & 1.00 & * & 1.00 & \\
\hline Young Sciencephiles & * & $*$ & 0.10 & * & * \\
\hline \multicolumn{6}{|l|}{ Facebook } \\
\hline Free-Timers & 1.00 & & & & \\
\hline Senior Sciencephiles & 0.24 & 0.24 & & & \\
\hline Intrigued Adolescents & * & $*$ & * & & \\
\hline Fully Employed Parents & 1.00 & 1.00 & 1.00 & $*$ & \\
\hline Young Sciencephiles & * & $*$ & * & 0.39 & * \\
\hline \multicolumn{6}{|l|}{ Blogs } \\
\hline Free-Timers & 1.00 & & & & \\
\hline Senior Sciencephiles & * & 0.05 & & & \\
\hline Intrigued Adolescents & * & $*$ & 0.65 & & \\
\hline Fully Employed Parents & 1.00 & 1.00 & 0.33 & * & \\
\hline Young Sciencephiles & * & $*$ & * & 0.65 & * \\
\hline \multicolumn{6}{|l|}{ Wikipedia } \\
\hline Free-Timers & 0.33 & & & & \\
\hline Senior Sciencephiles & * & $*$ & & & \\
\hline Intrigued Adolescents & * & * & 1.00 & & \\
\hline Fully Employed Parents & 1.00 & 1.00 & * & * & \\
\hline Young Sciencephiles & * & $*$ & 0.33 & 0.11 & * \\
\hline \multicolumn{6}{|l|}{ YouTube } \\
\hline Free-Timers & 0.15 & & & & \\
\hline Senior Sciencephiles & * & 0.81 & & & \\
\hline Intrigued Adolescents & * & $*$ & * & & \\
\hline Fully Employed Parents & 0.27 & 1.00 & 1.00 & * & \\
\hline Young Sciencephiles & * & * & * & 1.00 & * \\
\hline
\end{tabular}


Comparison 5: Other Contact

$\begin{array}{lrrrrl}\text { Museums } & \text { Non-CS } & \begin{array}{l}\text { Free- } \\ \text { Timers }\end{array} & \begin{array}{l}\text { Senior } \\ \text { Sciencephiles }\end{array} & \begin{array}{l}\text { Intrigued } \\ \text { Adolescents }\end{array} & \begin{array}{l}\text { Fully Employed } \\ \text { Parents }\end{array} \\ \text { Free-Timers } & * & & & & \\ \text { Senior Sciencephiles } & * & 1.00 & 0.68 & & \\ \text { Intrigued Adolescents } & 0.71 & 1.00 & 1.00 & 1.00 & 1.00 \\ \text { Fully Employed Parents } & 0.39 & 1.00 & 1.00 & 1.00 & \end{array}$

Zoos

Free-Timers

Senior Sciencephiles

Intrigued Adolescents

$\begin{array}{rr} & 0.09 \\ * & *\end{array}$

Fully Employed Parents

$1.00 \quad 1.00$

Young Sciencephiles

$1.00 \quad 0.38$

1.00

0.44

1.00

\section{Events}

Free-Timers

Senior Sciencephiles

Intrigued Adolescents

$0.97 \quad 0.22$

Fully Employed Parents

0.66

0.70

0.97

Young Sciencephiles

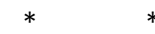

0.66

\section{Books}

Free-Timers

Senior Sciencephiles

Intrigued Adolescents

Fully Employed Parents

Young Sciencephiles

\section{Movies}

Free-Timers

Senior Sciencephiles

$1.00 \quad 0.08$

Intrigued Adolescents

$0.12 \quad 1.00$

1.00

Fully Employed Parents

$1.00 \quad 0.30$

1.00

* $\quad 1.00$

0.10

1.00

\section{Conversations}

Free-Timers

Senior Sciencephiles

Intrigued Adolescents

Fully Employed Parents

* $\quad 0.93$

0.34

* 0.93

0.81

Young Sciencephiles

0.34 